\title{
ANNUAL GENERAL MEETING OF THE FPS
}

THE President, the Marquess of Willingdon, took the chair at the Annual 1 General Meeting of the FPS, held at the offices of the Zoological Society of London, on April 29th, 1964. The minutes of the previous annual general meeting were approved and signed, and both the Auditors' Report and the Council's Annual Report were approved and adopted. The Marquess of Willingdon was re-elected President and Mr. I. D. Malcolmson Honorary Treasurer. Lord Willingdon welcomed Mr. and Mrs Fitter as, respectively, Honorary Secretary and Editor of ORYX, and expressed the sincere thanks of the Society to the retiring Secretary, Colonel Boyle, and to Mrs Boyle for all that they had done, and also the Society's regret at the resignation of Mr. John Hillaby, the Public Relations Officer. The President spoke of the need for all conservation organisations to work together, instancing the FPS, the Council for Nature, and the World Wildlife Fund, and hoped that closer links in the whole movement would be made. He thanked Sir Solly Zuckerman and the Zoological Society of London for providing the Society with office accommodation and for other help.

After expressing the Society's warm thanks to the three retiring members of the council-Dr. F. Fraser Darling, Mr. James Fisher and Mr. E. O. Shebbeare-the President proposed the election in their place of Mr. David Attenborough, Lord Craigton and Mr. R. C. Morris, and this was carried unanimously. Following the business, Mr. Fitter gave a brief account of the M'lilwane Game Sanctuary, the only wildlife sanctuary in Swaziland, which had been started by Mr. T. E. Reilly, a young and enthusiastic conservationist who had put all his personal savings into the project, and to whom the Society had sent a gift of $f, 100$. He also showed some slides of the sanctuary. In an illustrated talk Dr. R. M. Laws, of the Nuffield Unit of Tropical Ecology in Uganda, spoke on "The Ecology and Management of Hippopotamus in Uganda", and showed how a successful cropping scheme had been launched to cope with the overpopulation of the hippos in Queen Elizabeth National Park, and the beneficial effect of this on the habitat.

\section{PESTICIDES AND WILDLIFE}

GEVERAL important developments in relation to the effects of pesticides

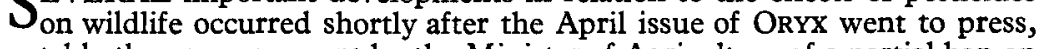
notably the announcement by the Minister of Agriculture of a partial ban on aldrin, dieldrin, and heptachlor. The fourth report of the Joint Committee of the British Trust for Ornithology and the Royal Society for the Protection of Birds showed that it is now the garden and insectivorous birds which head the list of birds affected by the chlorinated hydrocarbons. During the year, 304 out of 333 birds and forty-two out of forty-six samples of eggs analysed proved to contain varying quantities of chlorinated hydrocarbon pesticides, including sixty incidents relating to thirteen different kinds of birds of prey. Every one of eight samples of slugs and worms from fields and gardens treated with aldrinated fertilisers contained residues of dieldrin and DDT or its metabolites. The Committee seeks ultimately a complete ban on all chlorinated hydrocarbons, which it appreciates may be economically impossible at present.

At the international conference on birds of prey at Caen in April, reported on page 208 , one of the main recommendations was that the manufacture, storage, exportation, importation, sale, purchase and use in agriculture, forestry and similar activities of toxic chemicals as pesticides should be 
strictly controlled, and that extensive research should be carried out on these substances before they are used. Meanwhile the use of the more noxious chlorinated hydrocarbons should be prohibited immediately, and the others as soon as they can be replaced by less noxious ones, the ultimate aim being the elimination of persistent chlorinated hydrocarbons. All other pesticides should be subject to preliminary authorisation by the competent authorities of agriculture and public health.

The Report of the Agricultural Research Council's Research Committee on Toxic Chemicals recommended that although there are no major gaps in pesticides research at the present time, twenty-two specific points need attention, among them toxicological and biological studies in birds and wildlife generally, further ecological studies on whole populations of chosen species, and the contamination of fresh water by pesticides. In the United States " the biggest pesticides disaster to date " was disclosed in March, with the announcement by the U.S. Public Health Service that water pollution with endrin and dieldrin was the cause of massive and continuing fish kills in the lower Mississippi. Residues of DDT and DDE were also found in the bodies of the dead fish. Fish started dying by the millions in the lower Mississippi in 1960 following the first heavy use of endrin on sugar cane crops, and the numbers have increased each winter since.

A number of practical proposals were put forward at a symposium to consider progress in the safe use of pesticides, organised jointly by the chemical manufacturers and the conservation interests in London on March 16th, with Lord Howick in the chair, and Sir Solly Zuckerman to give the introductory address. These will be examined by the Joint Education and Communications Committee of the organisers. It is hoped to organise similar symposia on a regional basis throughout the country.

\section{Aldrin, Dieldrin and Heptachlor Banned}

On March 24th the Minister of Agriculture announced the results of a review of the use of persistent organochlorine pesticides, undertaken by his Advisory Committee on Poisonous Substances used in Agriculture and Food Storage. He accepted the recommendations of the Committee to ban the use of aldrin, dieldrin and heptachlor in farming, horticulture, gardening and food storage, except for certain highly specialised uses, and in particular to ban the use of dieldrin and aldrin in fertiliser mixtures and sheep dips as soon as this can be arranged. The Advisory Committee's remit will be extended to cover the use of organochlorine pesticides for industrial and domestic purposes, and the Committee itself transferred to the aegis of the Minister of Science and Education.

The FPS welcomes this development in Government policy, and the increasingly enlightened attitude of the chemical manufacturers, especially the withdrawal by two leading firms of aldrin and dieldrin products ahead of the official ban. Meantime, gardeners who have found it difficult to know what to do about garden pests when the only remedies they can find in the shops contain chlorinated hydrocarbons or other substances poisonous to birds and domestic pets, will welcome a booklet recently published by the Henry Doubleday Research Association, Pest Control without Poisons, by Lawrence D. Hills (HDRA, 20 Convent Lane, Bocking, Braintree, Essex, $3 s$.), which describes methods of controlling garden pests without resorting to the more modern chemical poisons. Pyrethrum and derris, or a mixture of both, are recommended as the safest pesticides for garden use, but $\mathrm{Mr}$. Hills also describes a wide variety of other devices for outwitting pests of fruit, flowers and vegetables, including the encouragement of hedgehogs and glowworms as predators on slugs and snails. 